\title{
コンデンサ分相形ヒステリシス電動機の 一解析法
}

$\begin{array}{llll}\text { 正員 涌 井 源二郎 } & \text { (茨城大) } \\ \text { 非会員 一八瀬 健 一 } & \text { (茨城大) } \\ \text { 正員 堀 井 龍 夫 } \text { (茨城大) }\end{array}$

\section{1.まえがき}

ヒステリシス電動機はかなり多方面に用いられてい るが，そのなかで最も多く用いられているのは音曊機 器駆動用である。との方面には単相運転が可能なこと から主としてコンデンサ分相形が用いられている。コ ンデンサ分相形は誘導電動機の場合と同様に, 円回転 磁界とならず，一般にだ円回転磁界となり多少とも逆 相分磁界を含む。しかむ，ヒステリシス電動機では逆 相分磁界による出力トルクの減少や一回転中の回転む らの発生など特性の劣化が大きいことがよく知られて いる。

ところで，これまでにヒステリシス電動機の特性解 析で逆相分㹡界の影響を初めて定量的に取报ったのは

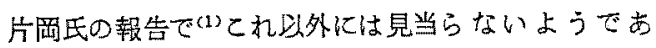
る。片岡氏は平衡二相電動機に不平衡二相電圧が印加 した場合の同期脱出時特性を正相分および逆相分等価 回路を誘導して解析している。

また，筆者の一人などのとれまでの報告(2)(3)(5)から 次のことが明らかにされている。(1)高調波には一般 に空間高調波と時間高調波の二種が考えられるが，基 本波磁界儿対する高調波磁鱼の作用は後で詳しく述へ るように，上記二種の高調波で同じ計算法が適用でき る。(2)高調波によるマイナループは大別して，(i) 高調波磁束密度一定（磁界の强さは変化する）のあの 亡, (ii)高調波磁界の強さ一定(磁束密度は変化する) の屯のの二種加考えられる。逆相分磁界す回転子上か らみれば一種の高調波（電源周波数の 2 倍）と考える ことができるから，逆相分にす上記（i），(ii) の二

An Analysis of Condenser Split Phase Hysteresis Motor. By Genjiro Wakut, Member, Kenichi Ichinose, Non-member, Tatsuo Horii, Member, (Faculty of Engineering, Ibaraki University)

诵井滰二郎：正員，茨城大学工学部電気工学科

一八濑健一：非会員，荻城大学工学部(現在，日立製作所日立工場）

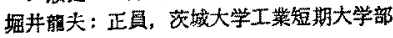

昭 $58-10$ 種のものが存在する（以後（i）の题合莸 $\triangle B$ 一定 な逆相分，（ii）の場合を $\Delta H$ 一定な逆相分之略称す る)。片岡氏は平衡二相電動機で固定子の漏れインピ 一ダンスによる麗压降下が比较的小さい埸合を取报。 ている(1)。このときは逆相分磁束密度が一定に近い場 合の解析をすべきである。しかるに，片岡氏の方法は むし万逆相分磁界の強さ一定の解析に近い上考えられ る。本文で対象としているコンデンサ分相形では固定 子インピーダンスは大きく，明らかに前記(i)，(ii) の二つの場合の中間上考えられる。このようなととか ら，コンデンサ分相形では逆相分の取り扱いはかなり 面搉になる。

本文では次のように取り扱った。磁束密度一定な逆 相分ば後で述べるように，取り扱いが簡単であること からまずこれを仮定して解析する。このようにして 求めた逆相分による出力トルクの減少は実際より小さ くなるが，これを補正するために等洒的に逆相分の透 磁率を小さくした。得られた同期脱出時の特性計算值 は実験值とよく一致し，この解析法が奖当なことが示 される。

\section{2. 正相分および逆相分回転磁界が加わった 場合の回転子内の $B-H$ 分布}

筆者らは，既に基本波に空間高調波が重衫合さった 場合の回転子内の $B-H$ 分布とてれらの場合の出力な どを理諭的に取扱って，と扎らは基本波江時間高調波 が加わった場合仪容易化拡張できること ${ }^{(2)(3)}$ ，また， これを方形波電圧で運転した場合のヒステリシス電動 機の特性解析などに適用した ${ }^{(6)}$ 。そこでは，理論上， 無限江存在する時間高調波を等価な最低次の一つの高 調波（等価 $n$ 。次調波之呼㣻）に招き加えて取り扱。 た。こてで取り扱う逆相分磁界も回転子上からみると きは電源周波数の 2 倍の時間調波と考えることができ るから等価 $n$ 。次謂波を逆相分磁界とおき加えるとと 
により,マイナループの部分を除いて(相違点は後述) 同様に取り扱うことができる。以下 $\Delta B$ 一定な逆相 分磁界が加わった場合について，回転子内の $B-H$ 分 布を調べる。ここでは詳細な説明は文献 $(1) ，(5)$, (6)を参照して戴き, 後の理論展開に必要な結果之相 違点を主として示す。

図 1 は逆相分磁界加存在する場合の同期脱出時，回 転子一極についての $B-H$ 関係を示したものである。 図でループ $L_{p}$ は正相分磁界 (磁束密度の最大値 $B_{f m}$ ) 之逆相分磁界（磁束密度の最大值 $B_{b m}$ ）の和 $B_{m}$ を最 大值とする直流ループで，逆相分が存在しないときの 一極の $B-H$ 関保を示し， その面積が脱出トルクを示 す。また, マイナループ af, $p^{\prime} q^{\prime}, p^{n} q^{\prime \prime} \cdots \cdots$ などは $B_{b_{m}}$ 一定（従って, $\triangle B$ 一定, $\Delta H$ は可変）なルー プで，主ループ $L_{p}$ 上(從って，回転子上の位置）で $\triangle B$ の変化しないループであり，この亡き，回転子内 ○ $B-H$ 関係はある瞬時ループ $L_{p}{ }^{\prime}$ (破線) で示され る。またループ $L_{p}{ }^{\prime \prime}$ は四のように，マイナループ の中点を結んだループで $L_{p}{ }^{\prime}$ を時間に対して平均した むので，正相分磁界淿よるループを示す。いま，ルー $フ^{\circ} L_{p}{ }^{\prime \prime}$ 上の座標を $\left(H_{f}, B_{f}\right)$ ，マイナループ上の座標 を $\left(H_{b}, B_{b}\right)$ とし, 瞬時ループ $L_{p}{ }^{\prime}$ 上の座標を $(H, B)$ とすると，

$$
H=H_{f}+H_{b}, \quad B=B_{f}+B_{b}
$$

いま, 回転子リング上の座標 $p \theta$ に対し

$$
\left.\begin{array}{l}
B_{f}=B_{f m} \sin p \theta \\
B_{b}=B_{b m} \sin (p \theta+2 \omega t)
\end{array}\right\}
$$

となる。ところで，トルクての一般式は次式で与えら れる(7)。

$$
\tau=\left(p V_{r} / 2 \pi\right) \oint B d H
$$

ここで， $p$ : 極対数， $V_{\tau}$ : 回転子リングの体皘， マ イナループの $B_{b m}$ はループ $L_{p}$ 上の位置で变化なく 一定であるが，H开仕異なるなどの点を考慮すると， 計算は不可能となる。そこで（3)式に(1)式孝代入 して平均トルクは次式のように与えられると考える。

$$
\tau=\left(p V_{r} / 2 \pi\right)\left\{\oint B_{f} d H_{f}-\oint \overline{B_{b} d H_{b}}\right\} \ldots
$$

ととで，(4)式第1 項はループ $L_{p}{ }^{\prime \prime}$ の面積，第 2 項 は平均のマイナループ面積を示すものとする。

\section{3. $\Delta B$ 一定な逆相分磁界が加わった場合の} 正相分，逆相分ループの透磁率とヒステ リシス角 ${ }^{(5)(6)}$

以下文献（5）の結果を利用して求める。図1亿お

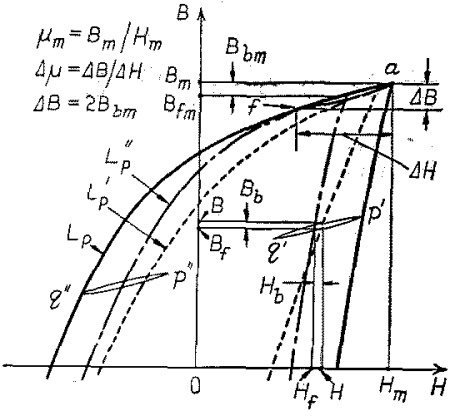

図1 回転子内の瞬時ループ $L_{p}{ }^{\prime}$, 等価ループ $L_{p}{ }^{\prime \prime}$ と直流ループ $L_{p}$

Fig. 1. Instanteneous loop $L_{p}^{\prime}$, equivalent loop $L_{p}{ }^{\prime \prime}$ and D.C. loop $L_{p}$ inside the rotor.

いて,

$$
\begin{aligned}
& \gamma=\Delta B / 2 B_{m}=B_{b m} / B_{m} \\
& B_{m}=B_{f m}+B_{b m}
\end{aligned}
$$

\section{ここで， $\gamma:$ 逆相分磁束密度含有率}

最大磁束密度 $B_{m}$ の直流ループ $L_{p}$ に対し, $\Delta B$ 定な逆相分（振幅 $B_{b m}=\Delta B / 2$ 一定）が加加ったとき の面積の減少分 ( $L_{p}$ 加ら $L_{p}{ }^{\prime \prime}$ の面皘を引いたすの) $S_{h}{ }^{\prime}$ は次式で求められる。

$$
S_{h^{\prime}}=2 \Delta H_{M} B_{m}\left\{1-\left(\Delta \mu / \mu_{m}\right)\right\}^{*}
$$

ここで, $\Delta \mu(=\Delta B / \Delta H):$ 主ループ $L_{p}$ の先端にお いて， $\Delta B$ を作用させてきまる堌分透磁率。 $\mu_{m}=B_{m} /$ $H_{m}$ (四I参照)。 $\Delta H_{M}$ : 文献 (5) で平均的 $\Delta H$ の 大きさ上定義されたもので，逆相分磁束密度の大きさ $(=\Delta B / 2)$ との間汇次の簡単な関係がある。

$$
\mu_{M b}=\Delta B / \Delta H_{M} \simeq 33.3 \mu_{0}
$$

ここで， $\mu_{0}$ : 真空の透磁率， $\mu_{M b}$ : 平均的逆相分透 磁率と定義する。

この $\mu_{M b}$ は普通回転子リングとして使用されるア ルニコ材（残留磁束密度 $B_{r}=9 \sim 10.5 \mathrm{kG}$ ，保磁力 $H_{c}=120 \sim 200 \mathrm{Oe}$ の範囲)(5)では材料のいかん並びに $B_{m}$ の值汇李関係なく一定で，(8)式が成立する。ま た，正相分ヒステリシス角 $\alpha_{f}$ は $\gamma$ の値に関係なく， 直流ループ $L_{p}$ のヒステリシス角 $\alpha_{2}$ と等しい。

直流ループ $L_{p}$ の面積 $S_{D}$ 沈次式となる。

*(7)式は $S_{h^{\prime}} \Delta H$ 一定な逆相分の揭合(2)(3) 之同し形の式で 埥わしたあので，相䏅点は $\Delta H_{M}$ だけである。四1で $\Delta B$ 一定

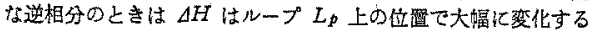

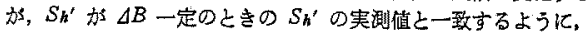

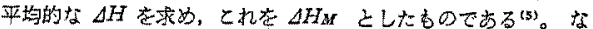
お, $\Delta H_{M}$ と $\Delta B$ との間䎲は(8)式の上うな簡單な関係があ

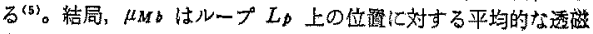
率と荅えるとえができる。 
$S_{D}=\left(\pi B_{m}^{2} / \mu_{2}\right) \sin \alpha_{2}$

$\mu_{2} ; L_{\mathrm{p}}$ において，磁束密度を正弦波之仮定したと き， $H$ はひずみ波となるが，その基本波の最大値を $H_{1 m}$ として $\mu_{2}=B_{m} / H_{1 m}$ ，同様に等価ループ (正相分 ループ） $L_{p}{ }^{\prime \prime}$ の面積 $S_{\&}$ は次式となる。

$S_{e}=\left(\pi B_{f m^{2}} / \mu_{f}\right) \sin \alpha_{f}=\left(\pi B_{f m^{2}}^{2} / \mu_{f}\right) \sin \alpha_{2}$

$S_{e}=S_{D}-S_{h}{ }^{\prime}$

(11)式の関係があるのだ，(7)，(9)，(10)式を

(11)式に代入して， $\mu_{\rho}$ 注次式の上うに求められる。

$$
\mu_{f}=\frac{(1-\gamma)^{2}}{\left(1 / \mu_{2}\right)-4 \gamma\left\{1-\left(\Delta \mu / \mu_{m}\right)\right\} / \pi \mu_{M b} K \sin \alpha_{2}}
$$

ここで，K: 補正係数，等価的に $\mu_{M b}$ を小さくす るための係数で $K<1$ ( $(3.3\rangle$ 節に䛨述)。

なお，(12)式において， $\mu_{f}$ は $\mu_{M b}$ 一定， $\mu_{m}, \Delta \mu$, $\mu_{2}$ などは $B_{m}$ の関数であるから，結局， $\mu_{f}$ は $\gamma$ と

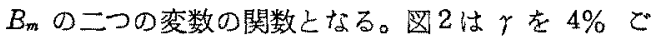
亡飞変化させたときの， $\mu_{f}$ 対 $B_{m}$ 特性を示したあの である。本解析法では第 3 章に述べるように，回転子 の正相分等価インピーダンスを計算機による反復副算 で求めているため， $\mu_{f}, \alpha_{f}\left(=\alpha_{2}\right)$ (実線) を数式化し て表放して㧍く必要がある。数式化住付録にゆずり， 近似曲線は図の破線のようになり，かなりよい近似で ある。なお，(12)式林吟味すると，(12)式の分

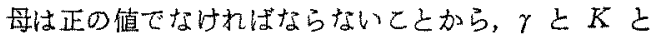
の間にはある制限が存在することになる。前述のよう 飞 $K<1$ であるから， $K \geq 0.4$ とする之 $\gamma<0.2$ でな ければならない。定格コンデンサ容量 $C=3.5 \mu \mathrm{F} に$ 対し， $C<5 \mu \mathrm{F}$ まで吟味しようとすると，乙のとき $\gamma$ $\leqq 0.2$ である。従って，以下 $0.4 \leqq K \leqq 1.0 ， \gamma \leqq 0.2$ の範囲で考えていくこととする。図2では各曲線の間 は $\gamma=4 \%$ の間隔があるので，二つの曲線の間の $\gamma$ 值に対する $\mu$ の值性比例関係汇あるとして計算を行 なった。

\section{3. 等価回路の誘導}

コンデンサ分相形ヒステリシス電動機の解析には非 線形な取り扱いが必要である。但し，非線形な取り扱 い吉回転子リングの磁気ヒステリシス現象に标いて， 正相分书よび逆相分磁気定数 $\left(\mu_{f} ， \mu_{b} ， \alpha_{2}\right.$ など) 求 める際に用いられる。このような磁気定数が求まる と，正相分および逆相分回路が決定され，乙れ以後は 線形な取り扱いが可能である。従って，コンデンサ分 相形誘導電動機上同じ形で等価回路が求まる。

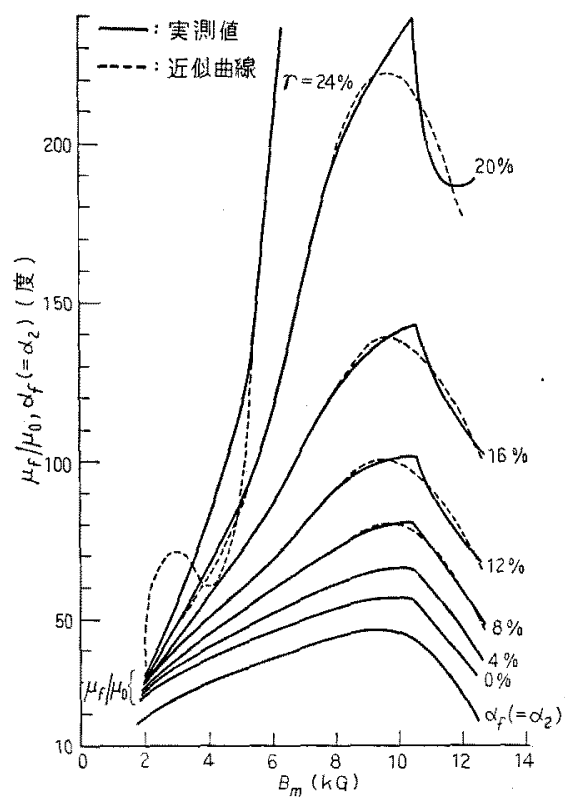

図 2 正相分ループ（等価ループ）に対する

透磁率 $\mu_{f}$ とヒステリシス角 $\alpha_{f}\left(=\alpha_{2}\right)$

Fig. 2. Permeability $\mu_{f}$ for positive-phasesequence component loop (=equivalent loop) and its hysteresis angle $\alpha_{f}\left(=\alpha_{2}\right)$.

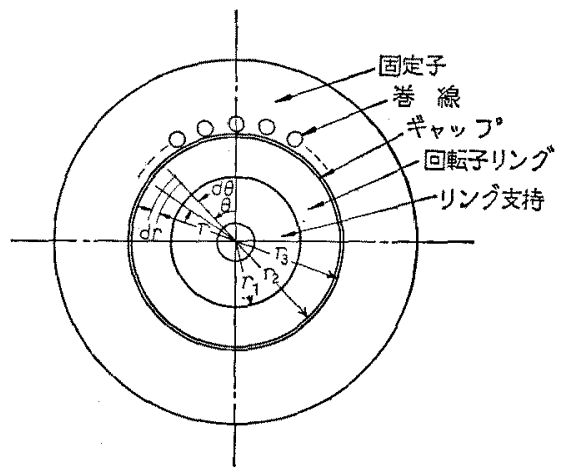

图 3 ヒステリシス電動機の断面図

Fig. 3. Cross section of hysteresis motor.

ここでは，容入氏が単相コンデンサモータについて 求めた $d, j q$ 軸等価回路をヒステリシス電動機に拡 張与る(9)。

図3はコンデンサ分相形篦動機の断面図で図のよう な円柱座標を考える。また，図 4 は回路図を示したる のである。ここで， $r_{1}+j x_{1} ， X_{0}:$ 主巻線の漏机イ ピーダンスとギャップ励磁りアクタンス, $r_{1 a}+j x_{1 a}$, $X_{p a}$ ：補助巻線の漏れインピーダンスとギャップ励磁 リアクタンス， $X_{\mathrm{c}}$ : 補助巻線に搜入したキャパシティ 


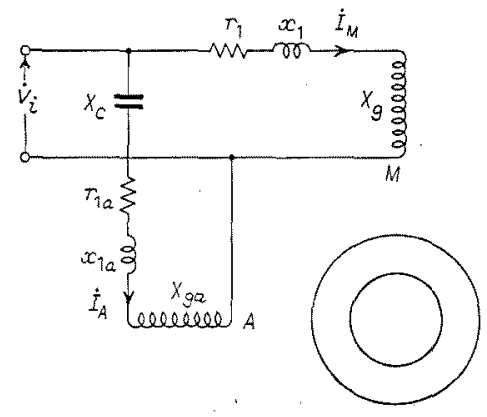

因 4 コンデンサ分相形ヒステリシス電動機

Fig. 4. Condenser-split-phase hysteresis motor.

ブリアクタンス。

一般に主巻線 $M$ と補助巻線 $A$ とは対称巻でない ので，普通よく行なわれているように $A$ 巻線を $M$ 巻楾亡同じ有效巻数に換算して图 50 回路加得られ る。この回路で $M$ 巻線と端子 $a^{\prime} a^{\prime \prime}$ からみた $A$ 巻 線とは対称巻であるから，これから図 6 の $f-b$ 軸等 価回路が得られる。

ことて， $\dot{Z}_{f} ， \dot{Z}_{b}$ : 回䎐子の正相分および逆相分イ ンピーダンスで，平衡三相ヒステリシス電動機の回転 子インピーダンスに批いて，正相分に対しては $\dot{\mu}_{f}$, 逆相分に対しては $\dot{\mu}_{M \sigma}$ で圈き换えたすのである。 $\dot{\mu}_{f}$ $=\mu_{f} e^{-j \alpha_{f},} \quad \dot{\mu}_{M b}=\mu_{M b} e^{-j \alpha_{M b},} \quad \alpha_{M b}$ は逆相分に対す るヒステリシス角で，普通 $\alpha_{M b} \simeq 0$ と近似する。 $Z_{f}$ ， Z゙は次式となる。

$$
\begin{aligned}
\dot{Z}_{f}= & 4 m \omega\left(K_{W 1} N_{1}\right)^{2} L \mu_{f} B_{-p} e^{-j\left(\pi / 2-\alpha_{f}\right)} \\
& \mid p \pi A_{+p} B_{+p} \ldots \ldots \ldots \ldots \ldots \ldots \ldots \ldots(13) \ldots \ldots \ldots(14) \\
\dot{Z}_{b}= & 4 m \omega\left(K_{W 1} N_{1}\right)^{2} L K \mu_{M b} B_{-p} \\
& \times e^{-j\left(\pi / 2-\alpha_{M b}\right) / p \pi A_{+p} B_{+p}} \ldots \ldots \ldots\left(A_{W 1} N_{1}\right)^{2} L \mu_{0} / p \pi A_{-p} k_{G}
\end{aligned}
$$

ここで, $R_{i}$ : 鉄損等価抵抗， $m:$ 相数 $(=2), \omega:$ 電

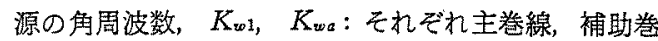
線の巻線係数， $N_{1}, N_{a}$ : それぞれ主巻線，補助巻線 の淃数， $L$ : 回転子リングの軸方向の長さ， $A \pm p=\left(r_{3} / r_{2}\right)^{p} \pm\left(r_{3} / r_{2}\right)^{-p}, \quad B_{ \pm p}=\left(r_{2} / r_{1}\right)^{p} \pm\left(r_{2} / r_{1}\right)^{-p}$, $a=\sqrt{X_{\theta} / X_{\sigma a}}=K_{w 1} N_{1} / K_{w c} N_{a}, k_{c}$ : カーター係数, $r_{3}, r_{2}, r_{1}:$ 図 3 参照。

图 $60 f-b$ 軸等洒回路を $d, j q$ 軸等価回路汇変换 した後，図5の $a \dot{V}_{i}$ と $V_{A}{ }^{\prime}$ 間を加えて図7の等価 回路が得られる。 $f-b$ 軸等伍回路之 $d, j q$ 軸等価回 路の間には文献（9）に明らかなように次の関係があ る。

$$
\left[\dot{V}_{d j q}\right]=[C]^{-1}\left[\dot{V}_{f b}\right]
$$

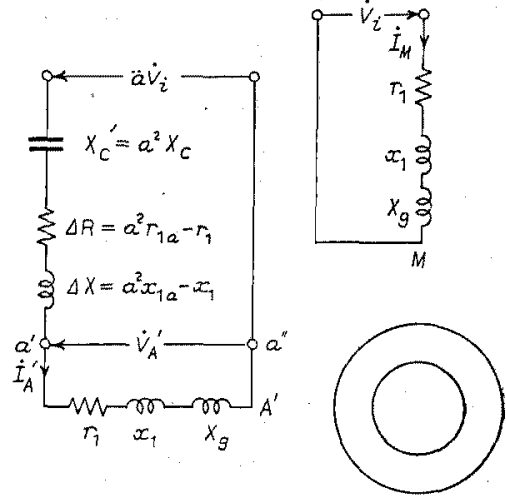

四 5 補助巻線の変換

Fig. 5. Transformation of auxiliary winding.

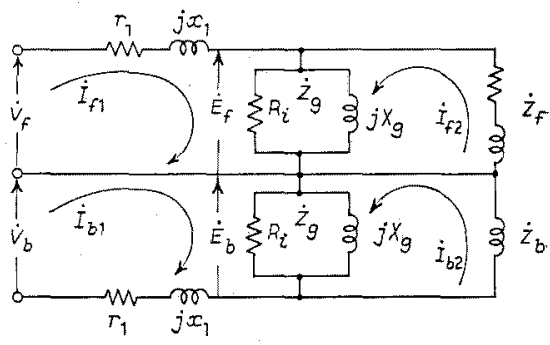

図 $6 \quad f-b$ 軠等価回路

Fig. 6. $f-b$ axis equivalent circuit.

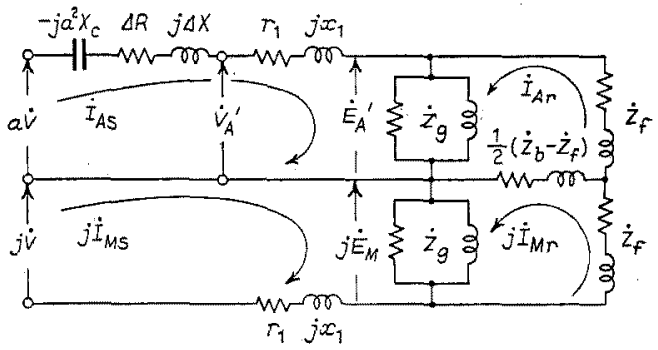

図 $7 d-j q$ 軸等価回路

Fig. 7. $d-j q$ axis equivalent circuit.

$\left[\dot{I}_{d j q}\right]=[C]^{-1}\left[\dot{I}_{f b}\right]$

ここで,

$$
\begin{aligned}
& {\left[\dot{V}_{d j q}\right]=\left(\begin{array}{c}
a \dot{V}_{i}-\dot{Z}_{c} \dot{I}_{A s} \\
j \dot{V}_{i} \\
0 \\
0
\end{array}\right), \quad\left[\dot{V}_{f b}\right]=\left(\begin{array}{c}
\dot{V}_{f} \\
\dot{V}_{b} \\
0 \\
0
\end{array}\right)} \\
& {\left[\dot{I}_{d j q}\right]=\left(\begin{array}{c}
\dot{I}_{A s} \\
j \dot{I}_{M s} \\
\dot{I}_{A r} \\
j \dot{I}_{M r}
\end{array}\right), \quad\left[\dot{I}_{f b}\right]=\left(\begin{array}{c}
\dot{I}_{f s} \\
\dot{I}_{b s} \\
\dot{I}_{f r} \\
\dot{I}_{b r}
\end{array}\right) \ldots \ldots \ldots \ldots \ldots \ldots \ldots \ldots \ldots \ldots \ldots}
\end{aligned}
$$




$$
\begin{aligned}
& {[C]=\frac{1}{\sqrt{2}}\left(\begin{array}{cccc}
1 & 1 & 0 & 0 \\
1 & -1 & 0 & 0 \\
0 & 0 & 1 & 1 \\
0 & 0 & 1 & -1
\end{array}\right) \ldots \ldots \ldots \ldots .} \\
& \dot{Z}_{c}=a^{2} r_{1 a}-r_{1}+j\left(a^{2} x_{1 a}-x_{1}-a^{2} X_{c}\right)
\end{aligned}
$$

$\langle 3 \cdot 2\rangle$ 特性計算の方法 図6，図7の等洒回路 を用いて特性計算を行なう。ここではまず，逆相分磁 束密度の大きさ $\Delta B / 2$ 一定で， $\alpha_{b} \simeq 0$ を仮定する。 これを(14)式に代入するとZbが求まる。実際には $\mu_{b} K=33.3 \mu_{0} K$ として，Kを1.0〜0.4の範囲で変 え，後述するように，最適な補正值 $K$ を決定する。 $\dot{Z}_{b}$ が決定しても， $\dot{Z}_{f}$ は回転子の磁束密度 $B_{m}$ 之逆 相分磁束密度含有率 $\gamma の$ 関数であるから，一義的低決 めることができない。

そこで，本文では以下の手順で $Z$ ，を決定する。図 7 の等価回路加ら各部電流山次式で表わされる。

$$
\begin{aligned}
\dot{I}_{A s}= & (1 / Y)\left\{\left(A_{2} D_{1}^{2}-F^{2} D_{1}-A_{2} D_{2}{ }^{2}\right) a \dot{V}_{i}\right. \\
& \left.+\left(-F^{2} D_{2}\right) j V_{i}\right\} \\
j \dot{I}_{M S}= & (1 / Y)\left\{\left(-F^{2} D_{2}\right) a \dot{V}_{i}+\left(A_{1} D_{1}^{2}\right.\right. \\
& \left.\left.-F^{2} D_{1}-A_{1} D_{2}{ }^{2}\right) j \dot{V}_{i}\right\} \\
\dot{I}_{A r}= & (1 / Y)\left\{\left(F^{3}-A_{2} F D_{1}\right) a \dot{V}_{i}\right. \\
& \left.+\left(A_{1} F D_{2}\right) j \dot{V}_{i}\right\} \\
j \dot{I}_{M r}= & (1 / Y)\left\{\left(A_{2} F D_{2}\right) a \dot{V}_{i}\right. \\
+ & \left.\left(F^{3}-A_{1} F D_{1}\right) j \dot{V}_{i}\right\}
\end{aligned}
$$

ここで,

$$
\left.\begin{array}{l}
Y=A_{1} A_{2}\left(D_{1}^{2}-D_{2}^{2}\right)-F^{2} D_{1}\left(A_{1}+A_{2}\right)+F^{4} \\
A_{1}=\dot{Z}_{c}+\dot{Z}_{1}+\dot{Z}_{g}, \quad A_{2}=\dot{Z}_{1}+\dot{Z}_{g} \\
F=\dot{Z}_{q}, \quad D_{1}=\dot{Z}_{q}+(1 / 2)\left(\dot{Z}_{f}+\dot{Z}_{b}\right) \\
D_{2}=(1 / 2)\left(\dot{Z}_{f}-\dot{Z}_{b}\right), \quad \dot{Z}_{c}=(21) \text { 式 } \\
\dot{Z}_{1}=r_{1}+j x_{1}, \quad 1 / \dot{Z}_{q}=\left(1 / R_{i}\right)+\left(1 / j X_{q}\right) \\
\Delta R=a^{2} r_{1 a}-r_{1}, \Delta X=a^{2} x_{1 a}-x_{1}
\end{array}\right\}
$$

因7 の回路で, ある入力電圧 $\dot{V}_{i}$ と $X_{c}$ において, 適当な $\dot{Z}_{f}$ を仮定する之，各部電流は (22) 式办ら求为 ること放できる。これより，図の誘起電圧 $\dot{E}_{A^{\prime}}, j \dot{E}_{M}$ は次のようになる。

$$
\left.\begin{array}{l}
\dot{E}_{A^{\prime}}=\dot{Z}_{g}\left(\dot{I}_{A s}+\dot{I}_{A r}\right) \\
j \dot{E}_{M}=\dot{Z}_{g}\left(j \dot{I}_{M s}+j \dot{I}_{M r}\right)
\end{array}\right\}
$$

上式を $f-b$ 軸沉変換して, 図 6 の誘起電圧 $\dot{E}_{f}$, $\dot{E}_{b}$ を求める。

$$
\left.\begin{array}{l}
\dot{E}_{f}=(1 / \sqrt{2})\left(\dot{E}_{A}^{\prime}+j \dot{E}_{M}\right) \\
\dot{E}_{b}=(1 / \sqrt{2})\left(\dot{E}_{A}^{\prime}-j \dot{E}_{M}\right)
\end{array}\right\}
$$

$\dot{E}_{f}, \dot{E}_{b}$ が求まると, 磁束と誘起電圧の関係から, $\gamma$ と $B_{m}$ が以下のように導かれる。

$$
\begin{aligned}
& \left|\dot{E}_{b}\right|=\sqrt{2} \pi K_{W 1} N_{1} f(2 S) B_{b m} \ldots \ldots(26) \\
& \left|\dot{E}_{f}\right|=\sqrt{2} \pi K_{W 1} N_{1} f(2 S) B_{f m} \ldots \ldots(27) \\
& |\dot{E}|=\left|\dot{E}_{f}\right|+\left|\dot{E}_{b}\right|=\sqrt{2} \pi K_{W 1} N_{1} f(2 S) B_{m}
\end{aligned}
$$

正相分および逆相分磁束密度は回転子リング内に一 様に浸透し，丹周方向に通ずるものとする。Sは回転 子リングの断面皘で,

$$
S=\left(r_{2}-r_{1}\right) L
$$

(26)～(28)式から， $r$ は次式で表わされる。

$$
\gamma=B_{b} / B_{m}=\left|\dot{E}_{b}\right| /|\dot{E}|=\left|\dot{E}_{b}\right| /\left(\left|\dot{E}_{f}\right|+\left|\dot{E}_{b}\right|\right)
$$

リング内の最大磁束密度 $B_{m}$ は次のように表わされ る。

$$
B_{m}=\left\{\left|\dot{E}_{f}\right|+\left|\dot{E}_{b}\right|\right\} / \sqrt{2} \pi K_{W_{1}} N_{1} f(2 S)
$$

(30)，(31)式で， $\gamma ， B_{m}$ が求まると，乙れを図2に 適用して，新らしい $\mu_{f}, \alpha_{f}$ 办求まり(13)式より新た に $\dot{Z}_{f}$ が求まる。以上述べた方法によって計算機に上 り $\dot{Z}_{f}$ が収束するまで反復計算する。てれを数回行な うと $\dot{Z}_{f}$ は一定値仅束する。この収束值 $\dot{Z}_{r}$ を用 いて，そのとき設定した入力電圧 $\dot{V}_{i}$, コンデンサ容 量に打りる脱出トルク，電流，力率，効率などを等価 回路より容易に求めることができる。

〈3.3〉 補正係数 $\boldsymbol{K}$ の決定 〈3.2〉節の上うに, $\triangle B$ 一定な逆相分を考えて解析すると，計算值は実測 值との間にかなり大きな誤差を生ずる。その理由は前 記したように，一次巻線仙屿此较的大きな漏れインピ 一ダンスのほかに, 補助巻線にはコンブンサによるか なり大きな外部インピーダンスが接続されているた め, $\Delta B$ 一定な逆相分の条件は成立していないためと 考えられる。結局， $\Delta B$ 一定之 $\Delta H$ 一定の中間の状 態汇あると推察できる。これは既に箻者の一人が明ら 加にたように， $\mu_{b}$ が等洒的に小さくなることであ る。本文では $\mu_{b}\left(=33.3 \mu_{o}\right)$ に $K(K<1)$ を采じて, 次の上うな適当な値となるように決定した。

入力電纴 $100 \mathrm{~V}$ において， $K=1.0 \sim 0.4$ の範囲で， 脱出トルクを計算し，夷測值を真の值としたときの平

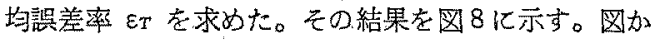
ら次のことがわかる。ほぼ円回転磁界に近い $C=3.5$, $4.0 \mu \mathrm{F}$ 付近では $\varepsilon_{T}$ は小さく，かつ $K$ の值関係な くほぼ一定である。これは逆相分磁界そのものが小さ いためである。Cかての值を離机るほど，巨TのKに 対守る依存性は大きくなる。乙机はその值を離れるほ 


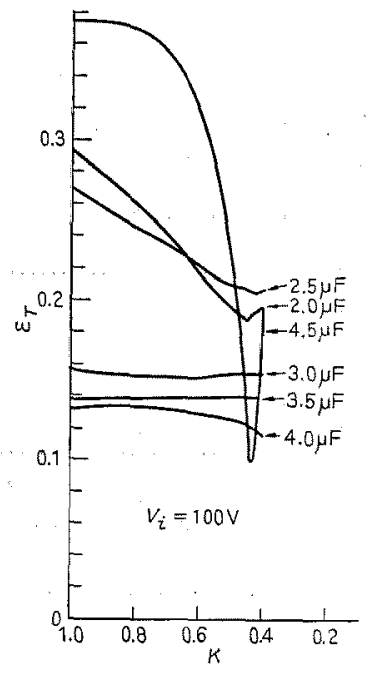

図 8 脱出トルクの平均誤差率対補正係数特性

Fig. 8. Average error rate characteristics of pull-out torque vs. correction factor.

ど，逆相分が大きくなり，しかすそれは $\Delta B$ 一定な 逆相分 $(K=1)$ でないてとを示している。

四から $K=0.45$ は $\varepsilon T$ がすべてのCの值に対し， ほぼ最小值に近く妥当であることがわがり，本文では $K=0.45$ 汇決定した*。

\section{4. 試料電動機による実測值と計算值}

〈4.1〉 試料電動機 単相 4 極, $50 \mathrm{~Hz}$ コンデン サ分相形ヒステリシス電動機で以下の仕㥞である。

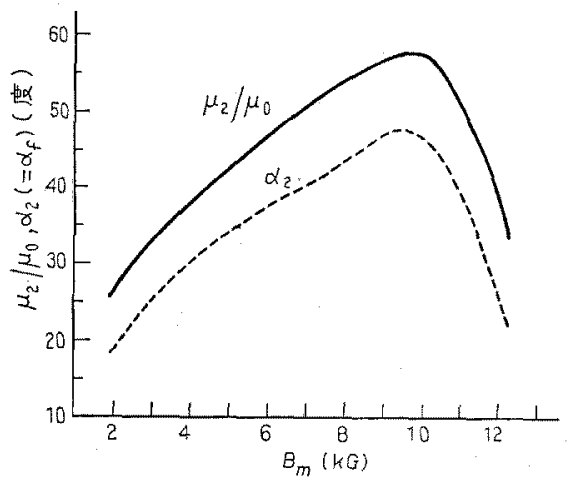

図 9 回転子リングの透磁率とヒステリシス角

Fig. 9. Permeability $\mu_{2} / \mu_{0}$ and hysteresis angle $\alpha_{2}$ of rotor ring.

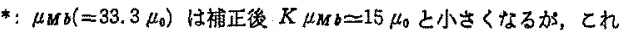
洁 $\Delta B$ 一定渞逆相分と $\Delta H$ 一定大逆相分の中間の場合に括ける

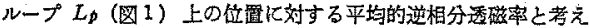
ることができる。

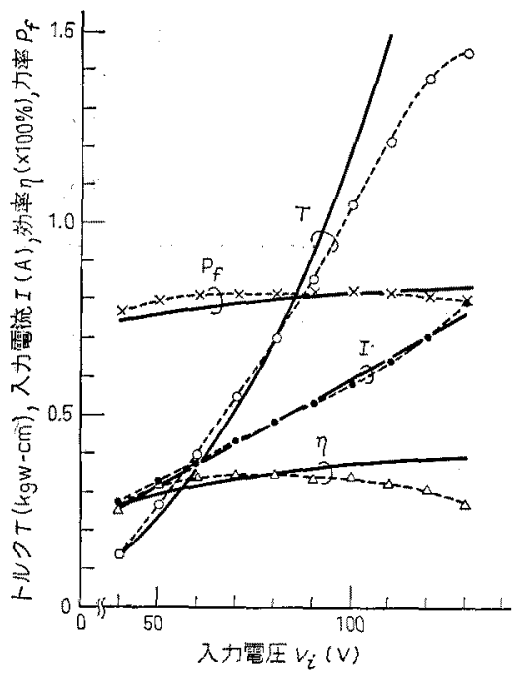

図 10 同期脱出時特性 $(C=3.5 \mu F)$

Fig. 10. Synchronous pull-out characteristics $(C=3.5 \mu \mathrm{F})$.

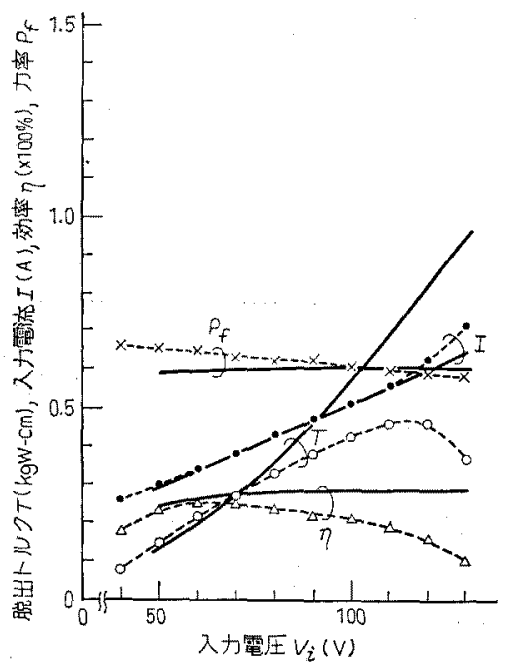

因 11 同期脱出時特性 $(C=2.0 \mu \mathrm{F})$

Fig. 11. Synchronous pull-out characteristics $(C=2.0 \mu \mathrm{F})$.

（1）固定子 主巻楾巻数：1,560 回, 補助巻線 巻数: 3,120 回，巻線ピッチ（主, 補助巻線之もに等し (): $4 / 6$ ，スロット数: 24 , 主巻線漏れインピーダン ス $r_{1}+j x_{1}=54.5+j 33.8 \Omega\left(28^{\circ} \mathrm{C}\right)$, 補助巻線漏徨 1 ンピーダンス $r_{1 a}+j x_{1 a}=205+j 133 \Omega\left(28^{\circ} \mathrm{C}\right), \quad 2 r_{3}$ $=51.2 \mathrm{~mm}$ ，固定子鉄心皘厚: $26.0 \mathrm{~mm}$ ，巻線係数 （主，補助巻線とも汇等しく） $K_{w 1}=K_{w s}=0.7887$ ，力 


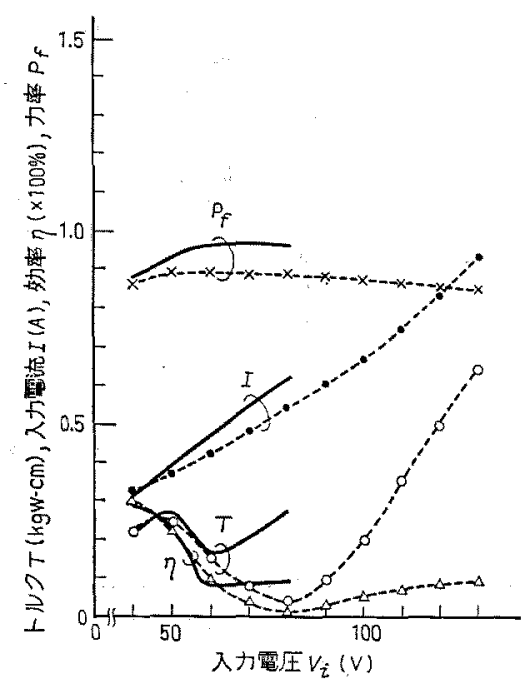

(a)

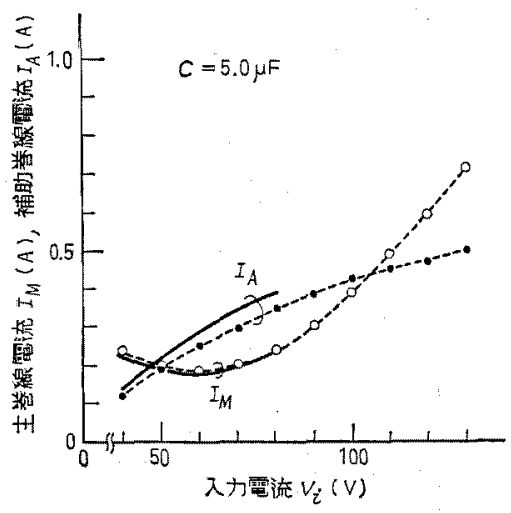

(b)

図 12 同期脱出時特性 $(C=5.0 \mu \mathrm{F})$

Fig. 12. Synchronous pull-out characteristics $(C=5.0 \mu \mathrm{F})$.

ーター俰数 $k_{c}: 1.125, R_{i}=2150 \Omega$ 。

(2) 回転子 $2 r_{2}=50.185 \mathrm{~mm}, 2 r_{1}=36.50 \mathrm{~mm}$ $L=26.1 \mathrm{~mm}$ ，試料機は定格コンデンサ容量 $2 \mu \mathrm{F}$ ，定 格電压 $V_{i}=100 \mathrm{~V}$ ，ギャップの長さ $0.2 \mathrm{~mm}$ のあの を $0.5 \mathrm{~mm}$ と大きくして空間高調波磁束の影響を極力 小さくした。 $C \simeq 3.5 \mu \mathrm{F}$ でほほ田回転磁界となる。

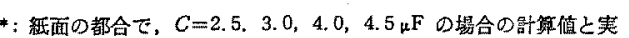

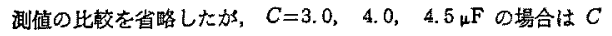

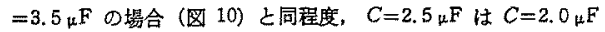

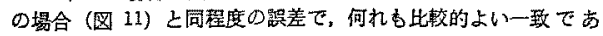
った。

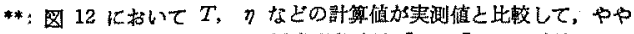

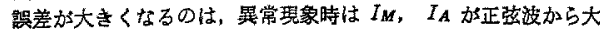
きく噰れたひず波となり，眭間高調波の影響が現われるためで

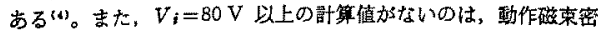
度 $B_{m}$ が图 2 で $12 \mathrm{kG}$ 以上となり，計算䇢睡外となるためであ る。

昭 $58-10$

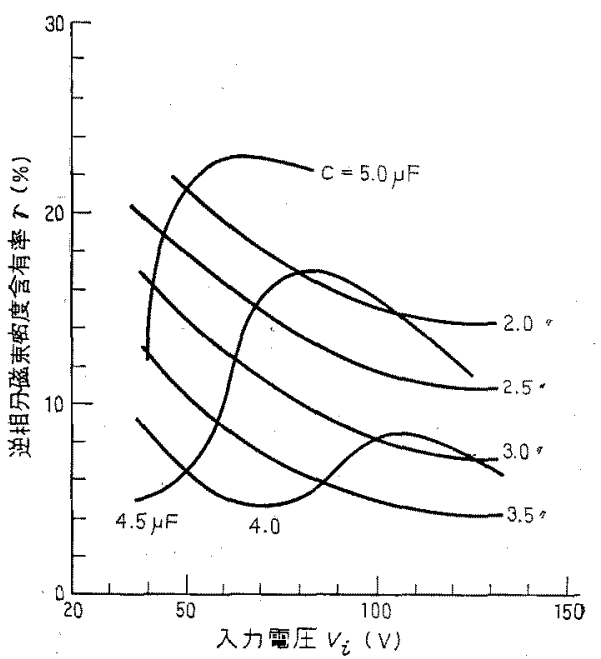

图 $13 r$ 対 $V$, 特性

Fig. 13. Content rate $\gamma$ of negative phase component of flux density vs. input voltage.

なお，回転子リングの磁気定数 $\left(\mu_{2} / \mu_{0}, \alpha_{2}\right)$ を図 $9 に$ 示す。

$\langle 4-2\rangle$ 実測值之計算值の比較 因 $10 \sim$ 図 12 K 脱出時特性を示す。 $K=0.45$ とするときは，Cの広 籍围の值にわたって，脱出トルク，電流，力率，効率 などすへて，実测値と計算值は比較的よく一致してお り，乙の解析法が要当であるととがわが。

$C$ が $4.5 \mu \mathrm{F}$ 以上に大きくなると，コンデンサ分相 形七ステリシス電動機に特有なトル夕異常愣象が発生 し，図 13 にみられるように，主巻線回路が並列鉄其 振状龍加それに近く，また，禣助巻線回路は直列鉄共 振状龍がそれに近い状態となり，脱出トルクに谷を生 ずる(図 12) が(4)，本解析法はこれらも含めては壮表 示できることが明らかとなっだ*。

\section{5. 容量 $C$ と $\succ$ との関係}

図10〜図12の脱出時特性において，主として回転 子リングの非線形特性のため，入力電王 $V$ 汶対する $r の$ 值は変化するとと恓考えられる。图 13 はその計 算㥀を示す。图加らケの最小値すなわち回転磁界儿 最む近いコンデンサ容量は $3.5 \mu \mathrm{F}$ と $4.0 \mu \mathrm{F}$ の間で あることがわかる。C=3.5 $\mu_{\mu} \mathrm{F}$ です $\gamma \simeq 4 \%$ で，逆相 分磁束密度をある程度含むととがわかる。 $C$ が 3.5 $\mu \mathrm{F}$ 以下のときは， $V i$ の增加ととむに $\gamma$ は単調に隇 少するのに対し， $C=3.5 \mu F$ 以上では， $V_{i}$ の増大と ともにやや複雑な変化をする様子がわかる。 


\section{6.むすび}

コンデンサ分相形ヒステリシス電動機は回転子が非 線形磁気特性のために，入力電E $V_{i}$ とコンデンサ容 量 $C$ が与えられても正相分和よで逆相分磁束密度な どは一義的に決定できいか，そのほ加に，逆相分磁 束密度が $\Delta B$ 一定の場合と $\Delta H$ 一定の場合の中間 に相当するなど解析は著しく困難である。

本文では，乙礼らを解決するために，（i）ます， $\Delta B$ 一定な逆相分磁束密度を仮定して $Z_{b}$ を決好る。 (ii) 他方で，回転子の磁気特性加ら， $B_{m}$ と $\gamma$ を与 えたときの $\mu_{f}, \alpha_{f}$ を求めておく(四2)。(iii) $Z_{f}$ を 仮定して， $f-b$ 軸等価回路亡 $d-j q$ 軸等価回路を用 いて， $Z_{f}$ を反復計算で決定し，最後に，(iv）Cの店 範囲の場合について，補正係数 $K$ を変えたときの， トルクの平均誤差率 $\varepsilon_{T}$ を求める。Cのいずれの值の 場合にあ $\varepsilon T$ 加最小または最小に近くなるように，最 適な $K$ の值を決定するすので，特性の計算值と実測 値の比較はよい。本解析法はこの種電動機の最適な設 計に直接役立てるととができると考える。

最後に試料電勤機はソニー（株）の佐々木，山本再 氏にかって御援助戴いたものであり，討諭，奏験に研 究室の久保田君，卒研生の諸君に助力して戴いた。以 上の方々に唇く感謝する。

(昭和 58 年 1 月 31 日受付，同 58 年 6 月 13 日再受付)

文献

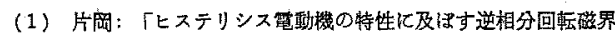

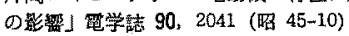

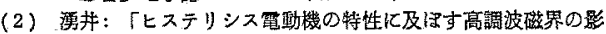

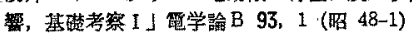

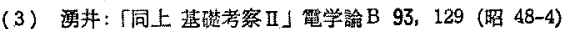

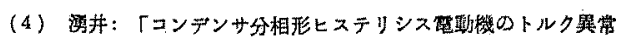
現象」電学諭B 92，89(昭 47-2)

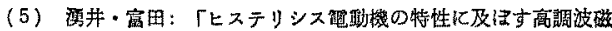

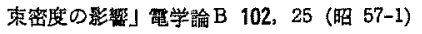

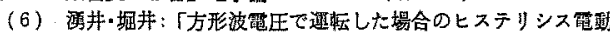
機特性の一解析法」酶学諭B 102,71 (昭 57-2)

(7) B.R. Teare, Jr: "Theory of Hysteresis Motor Torque" Trans. Amer. Inst. Elect. Engrs. 59, 907 (1940)

(8) 海半・草㺩: 「ヒステリシス電贁機の同期脱出トルりについ 乙了霓学誌 85, 1044 (䧄 40-6)

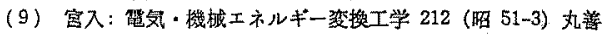

\section{付 録}

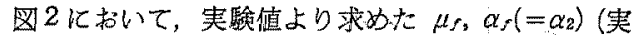
線)ををれぞれ $B_{m}$ に対する 5 次抽よび 4 次の多項式 で表わし，最小二乗法で近似曲線（破線）求めた。

$$
\begin{aligned}
& \mu_{f}=a_{0}+a_{1} B_{m}+\cdots+a_{5} B_{m}{ }^{5} \ldots \ldots \ldots \text { (付 } 1 \text { ) } \\
& \alpha_{f}\left(=\alpha_{2}\right)=b_{0}+b_{1} B_{m}+\cdots+b_{4} B_{m^{4}} \ldots \text { (付 } 2 \text { ) }
\end{aligned}
$$

ここて，(付1)，(付2)式の係数は付表1に示すと おりである。 $\gamma=24 \%$ では $B_{m}$ の低い方で近似曲線は 相違が大きくなるが， $\gamma$ が大きくなると， $B_{n}$ の大き い力のみが奏際の計算に必要であり支障はない。

付表 1 近仪多項式の係数

app. Table 1. Coefficient of approximate polynominal.

\begin{tabular}{l|r|r|r|r|r|r|r}
\hline & \multicolumn{1}{c|}{$\gamma$} & \multicolumn{1}{c|}{$a_{0}$} & \multicolumn{1}{c|}{$a_{2}$} & \multicolumn{1}{c|}{$a_{2}$} & \multicolumn{1}{c|}{$a_{3}$} & \multicolumn{1}{c}{$a_{4}$} & \multicolumn{1}{c}{$a_{5}$} \\
\hline \multirow{6}{*}{$\frac{\mu_{f}}{\mu_{0}}$} & 0 & 2.003 & 174.8 & -327.3 & 333.4 & -90.93 & -35.69 \\
& 4 & -5.444 & 252.2 & -561.2 & 693.7 & -337.6 & 23.69 \\
& 8 & -9.635 & 301.2 & -720.9 & 997.9 & -576.4 & 86.41 \\
& 12 & -26.86 & 489.4 & $-1,413$ & 2,243 & $-1,552$ & 357.9 \\
& 16 & -56.26 & -830.3 & $-2,784$ & 4,842 & $-3,658$ & 963.5 \\
& 20 & -195.9 & 2,396 & $-9,028$ & 16,160 & $-12,660$ & 3,550 \\
& 24 & $-1,329$ & 15,110 & $-59,650$ & 105,800 & $-83,040$ & 23,670 \\
\hline \multirow{6}{*}{$\alpha_{2}\left(=\alpha_{f}\right)$} & & $b_{0}$ & $b_{1}$ & $b_{2}$ & $b_{3}$ & $b_{4}$ & - \\
& & -8.460 & 207.3 & -448.4 & 519.0 & -224.2 & - \\
\hline
\end{tabular}

